\title{
Why do we feel burnout?
}

\author{
Ho Manh Toan \\ Phenikaa University

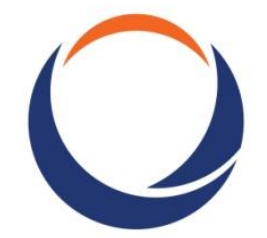 \\ PHENIKAA \\ UNIVERSITY
}

January 28, 2021

In her seminal essay "How Millennials Became The Burnout Generation," Anne Helen Petersen touched upon a definitive symptom of our generations: burnout [1]. She suggested that the millennials are famous for their laziness and the inability to grow up. Even for Petersen herself, she is also unable to complete many mundane tasks even though her career as a writer has been going smoothly. Later, Anne Helen Petersen developed this idea into a book named "Can't Even: How Millennials Became The Burnout Generation" [2]. Here, using the mindsponge mechanism [3,4] as the main framework, I would like to offer a hypothetical explanation for why we feel burnout?

So, in its simplest form, mindsponge is a learning and unlearning mechanism. The information goes in, and before they can reach the mindset, they have to go through many layers of stress tests. Even when they can enter the mindset, the mechanism continues to absorb and eject information, maintaining a flow of learning and unlearning.

We do not have a specific threshold yet; however, let consider a fully formed mindset when a person reaches 16 . By this age, a person has a complete background that constitutes their core cultural values in his/her mindset. After this age, hypothetically, the mindsponge will start to work at its full capacity. It is absorbing less, ejecting more. 
In this way, for the millennials born between 1981 and 1996, their mindset is constructed during a period of constant change. Their childhood belongs to a preInternet era. The input is from a few sources: the parents, relatives, friends from the neighborhood, or surrounding environment. Simply put, the core values in the mindset are culturally unique. They also share some generational characteristics, which derive from the condition of that time. In her essay, Petersen pointed out that economic stability and an expectation to optimize behaviors are some defining characteristics [1]. Here, I also want to suggest that the expectation of being kind and open-minded is also a notable aspect of being a millennial.

However, when they got older, the world has been changing quickly, such as technological advancement at an unprecedented speed. Most importantly, the information was still from surrounding environments only, and it had to be accessed physically too. On the contrary, the information that the millennials have to understand every day is larger and in various shapes and forms.

Here, let me bombard you with a load of information. In 1981, the world population was just around 4.5 billion people. By the end of 2019, the number has skyrocketed to 7.6 billion people. A person used to talk with a friend, send mail and watch TV on separate devices. Now, they only need a phone. The data generated from the smartphone do not make it easier for people. Within a day, around 294 billion emails are sent, 5 billion online searches are made [5]. The rate suggests that 463 exabytes of data ( 1 exabyte $=1000^{6}$ bytes) will be created in a day by 2025 [5].

So, the situation creates an unbalanced mindsponge process. The core values in the mindset of a millennial, used as the standard for evaluation, have to face an unparalleled volume of information. The mindsponge mechanism processes harder to evaluate and filter various kinds of new values. So, the millennials work harder subconsciously to keep up. In the era of globalization, where people are encouraged to be kinder and more accepting, the mindsponge process is also letting more new values in, and the mindset also gets more easygoing. Thus, the unbalanced mindsponge process is now struggling to release unsuitable values too. I suspect the role of cultural additivity will be important. In a country with complex cultural additivity like Vietnam $[6,7]$, contradictory values can be readily accepted.

In a way, this is a resource course for the millennials. As Vietnam's economy grows stably, companies that used too much capital and physical assets would perform poorly $[8,9]$. It is also similar to the millennials. They have too many resources: traditional knowledge, new technology, economic stability, and so on. There is no 
perfect way to fully optimize behaviors in such a condition, so the effort to optimize makes the system crash.

\section{References}

[1] Petersen, A. H. (2019). How millennials became the burnout generation. BuzzFeed News. Retrieved from https://www.buzzfeednews.com/article/annehelenpetersen/millennials-burnoutgeneration-debt-work

[2] Petersen, A. H. (2021). Can't Even: How Millennials Became the Burnout Generation. Random House.

[3] Vuong, Q. H., \& Napier, N. K. (2015). Acculturation and global mindsponge: an emerging market perspective. International Journal of Intercultural Relations, 49, 354-367.

[4] Vuong, Q. H. (2016). Global mindset as the integration of emerging socio-cultural values through mindsponge processes: A transition economy perspective. In J. Kuada (ed.) Global Mindsets: Exploration and Perspectives (pp. 109-126). London: Routledge.

[5] Desjardins, J. (2019). How much data is generated each day?. World Economic Forum. Retrieved from https://www.weforum.org/agenda/2019/04/how-muchdata-is-generated-each-day-cf4bddf29f/

[6] Vuong, Q. H., et al. (2020). On how religions could accidentally incite lies and violence: Folktales as a cultural transmitter. Palgrave Communications, 6, 82.

[7] Vuong, Q. H., et al. (2018). Cultural additivity: Behavioural insights from the interaction of Confucianism, Buddhism, and Taoism in folktales. Palgrave Communications, 4, 143.

[8] Chính, P. M., \& Hoàng, V. Q. (2009). Kinh tế Việt Nam: Thăng trầm và đột phá. Nxb Chính trị Quốc gia, Hà Nội.

[9] Vuong, Q. H., Napier, N. K. (2014). Resource curse or destructive creation in transition: evidence from Vietnam's corporate sector. Management Research Review, 377), 642-657. 